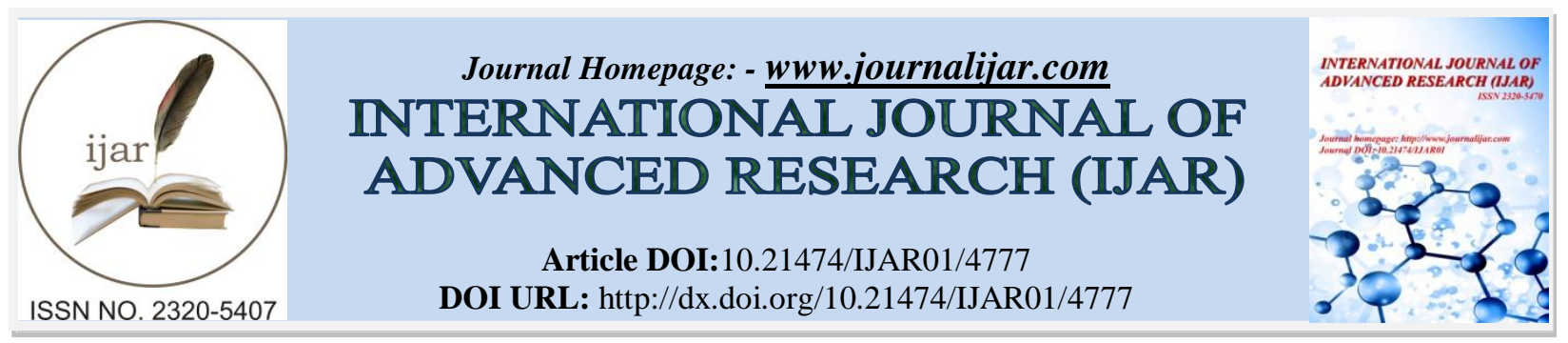

RESEARCH ARTICLE

\title{
RIGHTS OF TRANSGENDERS: A CONSTITUTIONAL PERSPECTIVE VIS-À-VIS CRIMINAL JURISPRUDENCE.
}

\author{
Rattan Singh ${ }^{1}$ and Shikha Dhiman ${ }^{2}$.
}

1. Professor, University Institute of Legal Studies, Panjab University, Chandigarh.

2. Research Scholar, Department of Laws, Panjab University, Chandigarh.

\section{Manuscript Info}

.....................

Manuscript History

Received: 7 May 2017

Final Accepted: 9 June 2017

Published: July 2017

Key words:-

Equality, Third Gender and Transgender.

\section{Abstract}

All human beings are the creature of God and therefore all should be treated equally irrespective of their caste, color, sex, gender identity and sexual orientation. Transgenders are the human beings and we need to respect them with full dignity. We are no one to discard them or disrespect them in any form. No doubt transgenders are given full right to life and personal liberty but in actual these rights get restricted in one way or the other. Constitution of India guarantees the rights and freedom to all persons including transgenders but the reality is different. Such people are not treated with respect and human dignity. Just because of the infringement of rights of transgenders, the issue is taken up before the Apex Court which pronounced a landmark judgment in this regard. Supreme Court was very firm in its decision as to provide equality of status and opportunity to transgenders living in society. Also, there are many organizations in India who give new face to transgender community by fighting for their rights. Transgenders achieved victory in 2014, when Supreme Court of India declared the 'Transgender' as 'Third Gender' and held that nonrecognition of third gender for civil rights is violative of Fundamental Rights guaranteed under Part III of our Constitution of India.

Copy Right, IJAR, 2017,. All rights reserved.

\section{Introduction:-}

We are living in a society where we have constantly tried to neatly contain the humankind within two traditional unbending gender categories i.e. males and females whereas other category of people include bisexuals and transgenders. Civil society all around the world, particularly in India, is yet to come to terms with their existence, even though time and space stands as a proof of their existence. In India, for instance, the earliest recorded evidence of transgendered people community dates back to more than 4000 years back and finds mention in Ramayana as well as Mahabharata and numerous other mythical legends of India. These legends depict that such community people in India had sanctioned their role in Hindu society especially through the practice of bringing 'good wishes' to a family in northern India. ${ }^{1}$ In spite of their recorded presence and history that has been attached to them, such transgendered community, till date, remains a neglected and marginalized community i.e., a community that is just not fighting for the rights but also working hard to get recognition from other people. When the question is about the

\footnotetext{
${ }^{1}$ Manu K. and Sudhanshu Roy, Transgenders, Vulnerability and the Law in India, (Mar. 02, 2015, 06:05
} PM),http://www.legalindia.com/. 
rights and freedoms, don't we think that these transgenders should also be granted the same? Are they not the human beings who can claim the same rights and freedoms? What is the status of such people in our society? What is their fault if they are born in such a way? Their birth does not mean that they should not be granted such rights. Transgenders are facing the problems which are usually not faced by non-transgendered persons. When we talk about the rights, it means those privileges which are granted for the benefit and welfare of the people by the State. Transgenders are the creation of God and yes, they equally have the right to claim to for their "Rights". Constitution of India guarantees various rights to such people and states itself that no discrimination is sought to be made on the grounds of 'sex'. But in our society, people still have orthodox view about transgenders and they do make discrimination in present times. With the passage of time, things might have changed but the entire scenario is still not favoring such people. Such community still faces much discrimination in various fields like health care, employment, education levels and sexual orientation etc. Apart from many constitutional rights and freedoms, there are other rights as well which are claimed by transgenders. Few of such rights are right to change legal gender, right against discrimination, right to adoption by transgender, right to inheritance, right to succession and many more. These rights are, up to some extent, being given to transgenders in our society. Transgendered people are also like humans and just by the reason being that they are physically different; it does not make a valid ground for any one of us to discriminate with such people. According to traditional view, the blessings of these people were supposed to be something very generous and on account of marriages or on the birth of baby boy, people usually call them in order to seek their blessings. Had this been the situation, then why people think of not giving them their basic rights? Why they have been discriminated on one or the other grounds? The issue seems to be very much ignited. People nowadays have to change their mental level so that they can respect such people in a similar way and give them their rights in a way they want them to be.

\section{Right to Equality under Article 14, 15 and 16:-}

Our Constitution provides us with the Right to Equality. The concept of right to equality in the Constitution is prescribed under the provisions of Article 14, 15 and 16. These provisions grant the fundamental right to the persons i.e. citizens as well as non citizens. These equality rights talks about providing the equality to all the persons, be it in case of employment or in case of prohibition of any sort of discrimination or in case of providing equality before the law. The concept of equality has also been stated in the Preamble thereby mentioning to provide equality of status and of opportunity.

\section{Transgenders vis-a-vis Article 14, 15 and 16:-}

Article 14 of Indian Constitution i.e.Equality before Law states - "The State shall not deny to any person equality before the law or equal protection of the laws within the territory of India." Our Constitution makers were of the opinion that no person within the territory of India should be denied these rights. They knew that even though Lord Budha was one of the earliest proponents of equality in this land followed by many others, wide spread social and economic inequalities sanctioned by the public policies and exercise of public power, supported by religion and other social norms and practices, still existed. Such inequalities could not be removed or dealt with by a provision like Article 14 alone. Even if they could be dealt with, it would have been a very slow process. Therefore, they expressly abolished and prohibited some of the existing inequalities practiced not only by public power or State but even by private persons, and expressly authorized the State to take necessary steps to minimize and remove them. Article 15 to 18 clearly expresses such intention of the Constitution makers. ${ }^{2}$ These all questions do create hassle in the mind of a common man. No doubt, Article 14 deals with both positive and negative aspect of equality. The first part talks about "equality before law" whilst the second part throws light on "equal protection of laws". Keeping this provision in mind, few questions arises about considering the equality principle with regard to transgenders like What is there status in society with regard to giving of equal opportunity? Are they been given equal status in society? Are they provided with same rights? and many more. With regard to Article 14 of Constitution, queries were being raised in Supreme Court when Section 377 of Indian Penal Code, 1860 was in question. It was agitated: whether "the order of nature" could form the basis of classification in the context of the right to equality under Article 14? and whether there was such a universal order of nature? The debate was that whether the reasonable classification which we study under Article 14 can be claimed by these transgenders? Do these people fit under the category of "reasonable classification"? The answers to these questions lead to landmark judgment. However, under the provisions of Article 15 and 16, the State is not allowed to discriminate on the basis of "sex". Can the State be asked not to discriminate on the basis of sex when the question of transgenders is involved? This query was also, however, put up in the landmark case dealing with Section 377 of Indian Penal Code, 1860.

2 V.N. Shukla, Constitution of India 47-48(Lucknow, Eastern Book Company, 2013). 


\section{Fundamental Freedoms under Indian Constitution:-}

As far as Article 19(1)(a) of Constitution is concerned, it can be asked that whether the right to speech and expression also includes freedom of sexual expression? Freedom and equality are further strengthened by the Court's observations on dignity, privacy, personhood and the free spirit of the human being, which are necessary for the human 'personality to flower to its fullest ${ }^{3}{ }^{3}$ Our Constitution grants us various fundamental freedoms but are the same freedoms given to these transgenders as well? The question is unanswered yet. In our society, these people have been given some status but yet not up to the level of other people. Where other people can rightfully claim these fundamental freedoms, transgenders cannot go for it. Following is the brief description about the six fundamental freedoms, namely:

1. Freedom of Speech and Expression: As far as transgenders are concerned, does this right to speech and expression include freedom of sexual expression? Whether these people can be granted this freedom without any distinction on the basis of sex? The bare provision of Article 19 (1) (a) does not talks about making any distinction on the basis of sex, which thereby implies that these people can be given this freedom without any discrimination. But however many a times instances have been seen when these people does claim for their rights and they have been restricted for doing the same. Isn't this the violation of their fundamental right to speech and expression? What status is given to such people in that context? Being the citizens of the nations, if others are given the same freedom then why their freedom is restricted? We know when the issue of Section 377 of Indian Penal Code, 1860 was raised up in the courts; such people used their fundamental right of speech and expression. In fact they should be given full chance to raise their voices, in case anything is being done against them. We live in democratic nation so we need to fulfill the objectives of our society without discriminating on any ground. But keeping this freedom in mind, one should know that this freedom is not an absolute one, rather it does have some reasonable restrictions attached with it under Article 19 (2) i.e., in the interests of sovereignty and integrity of India, security of the State, friendly relations with the foreign States, public order, decency or morality, contempt of court, defamation and incitement to an offence. So it implies that only on the basis of these grounds this fundamental freedom may be restricted which is being granted citizens but not on the ground of 'sex'.

2. Freedom to assemble peacefully and without arms: Every citizen of the nation has the right to assemble peacefully and without arms. The Constitution secures this right to the citizen subject to two limitation: (a) the assembly must be unarmed; (b) it must be peaceful i.e. it must not be tumultuous or riotous in character. ${ }^{4}$ Further, under clause (3) of Article 19, the State may impose reasonable restrictions as may be deemed necessary in the interests of public order or the sovereignty and integrity of India. The same concept applies to transgenders and they have the full freedom to assemble peacefully and without arms within the territory of India.

3. Freedom to form associations or unions or co-operative societies: Transgenders should also be given the freedom to form any associations or unions, subject to the restrictions provided in our Indian Constitution.

4. Freedom of movement throughout the territory of India: The transgenders have been given full freedom to move throughout the territory of India. Initially the problem was there in the passport of such people wherein it becomes tedious that in which category they fall. But since the passing of the judgment ${ }^{5}$, the Court has granted the special status to these people and recognized them as 'third gender'.

5. Freedom to reside and settle in any part of the territory of India: Most of the population of transgenders resides in Southern States like Tamil Nadu, as this State being one of the States which favored the rights of transgendered people. So as such, there has been no restriction placed on them to freely reside and settle in any part of the territory of India. Though Constitution guarantees this freedom, still States have their own local laws which directly or indirectly harass this community.

6. Freedom to practice any profession or to carry on any occupation, trade or business: This freedom is not given to transgenders in entirety because of some issues prevailing in our society.

\footnotetext{
${ }^{3}$ DhananjayMahapatra, Supreme Court recognises the Right to determine and express ones gender grants legal status to third gender, (Sept. 01, 2016, 02:05 PM) http://www.lawyerscollective.org/updates/supreme-court-recognises-the-right-to-determine-andexpress-ones-gender-grants-legal-status-to-third-gender.html.

${ }^{4}$ V.N. Shukla, Constitution of India 156(Lucknow, Eastern Book Company, 2013).

${ }^{5}$ National Legal Services Authority v. Union of India, W.P. (C) No. 604 of 2013.
} 


\section{Glance at Article 21 with respect to Transgenders:-}

Article 21 talks about "right to life and personal liberty". As per our Indian Constitution this right is granted to every person, be it a citizen or non citizen. Article 21 states: "No person shall be deprived of his life or personal liberty except according to procedure established by law." No doubt, transgenders are provided with right to life but does our society really provides them with adequate facilities of right to life which is enjoyed by other people. The answer sounds to be No. The concept of right to life includes many other perspectives and it has other expanding horizons. Earlier in the case of A.K. Gopalan v. State of Madras ${ }^{6}$, the court went on giving a very narrow interpretation to right to life and personal liberty. The courts opined that there is no relation as such between Article 21 and 19. But Justice Iyer was of the view that Article 21 cannot be confined one and we need to look it through a broader point of view. This actually happened in the post Gopalan's case and in the year 1978, there came the renounced judgment of Maneka Gandhi v. Union of India ${ }^{7}$, wherein the courts ended up saying that Article 14, 19 and 21 are interlinked and can't be separated and since then a wider interpretation has been given to the Article 21 of Indian Constitution. The various notions of "right to life", with respect to transgenders can be understood as under:

a. Right to live with human dignity: Talking about human dignity, the first thing that strikes in our mind is that do these people are really living in our society with full dignity? The answer may be No. Their right to live with human dignity is usually violated as they are not given the same status as compare to other people living in the society. They do live in the society but not with the same respect as being given to other people. So it becomes the duty of the other people living in society to let these people live with more respect and human dignity. It is articulated that in comparison to earlier times, present day people yet give little more respect to transgenders but not equivalent to other as expected by them (transgenders).

b. Right to privacy: Usually, their right to privacy is infringed by other people thereby violating their right to life.

c. Right to shelter: Shelter means a place to live and stay together. Truly, people living in localities never want that transgenders should live nearby which, therefore, abridges their right to shelter and resultantly, right to life.

Apart from the above mentioned rights, many other rights started coming under the purview of right to life. With the various pronouncements of our Apex Court, many times cases came up that finally started considering few of the directive principles under the provisions of right to life. Those were like Right of every child to a full development, Right to live in a healthy and clean environment and many more.

Talking about transgenders, few of the rights are undoubtedly granted but not with that dignity and respect. Why the actual practice is different? Had they been given everything equally, issues would have never raised up involving transgenders and their activities as something unnatural or beyond the human nature. When the child is born as transgender, the parents tend to throw their child out of the home or they want the other transgender to come and take their child along with them. Parents at times are forced to do all these acts because of the mindset of the society. Isn't this activity is itself inhumane treatment to the born child? What is his fault? Just that he/she is born as a transgender. But the question can arise that how the child is born as transgender if parents are normal? It is related to out biological issues i.e. Chromosomal Aberration. Let's say, now even if he is born in such a way, does that mean that he has no right to life in the society like other children have. Right to life is itself enshrined in our Constitution and the violation of such right to transgenders should itself be criminalized in a way like untouchability is criminalized.

\section{Article 21A for Transgenders:-}

Education is part and parcel of every child's future. Every child in a society is supposed to get an education at least upto the basic level. Right to education was initially not included as a fundamental right in the Constitution and but included as a Directive Principle under Article 45 which required the State to endeavor to provide, within a period of 10 years from the commencement of the Constitution, for free and compulsory education for all children until they complete the age of 14 years. ${ }^{8}$ However it had always remained crucial for the State to provide education to the children as these children are considered to be the future of our nation. The Directive Principle under Article 45 was not confined merely to primary education; it extended to providing free education upto the age of 14 years, whatever the stage of education it came to. ${ }^{9}$ Within the passage of time, Supreme Court in many of the judgments pronounced that "right to education" comes from other Articles of the Constitution such as Articles 21, 24, 30(1) and 39(e) and

\footnotetext{
${ }^{6}$ A.K. Gopalan v. State of Madras, AIR 1950 SCR 88.

${ }^{7}$ Maneka Gandhi v. Union of India, AIR 1978 SCR 597.

${ }^{8}$ M.P. Jain, Indian Constitutional Law 1227 (Gurgaon, Lexis Nexis, 2014).

${ }^{9}$ Ibid.
} 
(f). In Unnikrishnan ${ }^{10}$, the Supreme Court once again reiterated that right to education flows from right to life and personal liberty. Subsequent to Unnikrishnan case,Article 21A was added by the $86^{\text {th }}$ Amendment, 2002 which finally made the right to education as a fundamental right. When the question comes about right to education, what can be said about right to education of transgenders? In our society whether these people are treated equal to other children? These are the top priority questions which need to be discussed in our society. We know that society doesn't remain static. Society changes with the time and so does the attitude of people towards various things. As far as the education of these transgenders is concerned, it can be dealt under two aspects: earlier view and present $21^{\text {st }}$ century view.

\section{Earlier views of Right to Education of Transgenders:-}

In the earlier days, people were least concerned about the education. We know that the girls in some villages and cities were not even allowed to study up to the basic education level. The main purpose, in initial days, was to educate the boys so that they can earn the livelihood for their families. The situation was almost same with regard to transgenders. Such people was never considered part and parcel of the society itself. Those falling under these categories were not supposed to get education. They were basically ill-treated in society. Even if they feel like to build up their career in some other field of their interest, the same were restricted for one or the other reasons. The society was never in favor of building these kinds of children or to provide them education. Such children since their childhood were ignored and were given least importance in every aspect. Granting education to them was something that can never be thought of. If any percent of people in society would ever think of granting them few basic rights, other majority won't let them do so. Moreover apart from the society, the people belonging to this category also never used to claim for their rights. So it can be well enunciated that in earlier days, apart from any other right, even this basic right to education was not given to them.

\section{Views of $21^{\text {st }}$ century for Right to Education of Transgenders:-}

We all know that things are bound to change. Nothing remains constant in this world. With the change in time and scenario, approach of people also changes. With so many changes in Constitution, this Right to Education was also made as one of the Fundamental Right under Part III of Constitution. As we discussed above, transgenders were not given due status in society in earlier days. But gone are the days when these used to be the circumstances. The present scenario has changed everything. In today's era of $21^{\text {st }}$ century, education is considered as one of the important tool of a person. But when the question comes of granting education to transgenders, society has turned their views on this issue. Nowadays, people give due recognition to transgenders and such categories of persons are not denied with their basic right to education. They have the full power to claim this right. Apart from the basic level of education, even in the higher degree of education, they are given due recognition. Such people are given quota for the same. In today's arena, transgenders are not discarded by the society but in fact they are given full equality rights and opportunities in all the aspects including educational field. We live in a democratic and socialist State and none of us has the right to infringe the rights of another. Transgendered people are the members of our society only, then how can a person think of not giving them their basic right i.e. right to education? Courts have many a time pronounced about the importance of this particular right. Our Constitution makers always intended to make such provisions in Constitution which will turn out into the overall benefit of the citizens of India. No such distinction on the basis of caste ever arose in their mind. Now if our Constitution framers did not ever intend to make distinction between such kind of people, how can we the people can dare to abrogate any of the rights of transgenders. In our present times, the ideology of people has changed tremendously with regard to these transgenders. Any person who belongs to either of this transgendered category can never be denied his right to education, if the person or his parents wish him to get education.

\section{Inclusion of a column - "Third Gender":-}

We know that what role education play in our life. How much preference is given to an educated person rather than an uneducated man? Since the very initial times, there has been lots of controversies with regard to the "sex" of such transgenders that whether they are covered under "males" or under "females". The burning controversy was as to in which category such people fall. As and when the matter has been taken up to the judiciary, judiciary could never find a good solution to that. It was because of this reason that many a time whenever such persons feel like filling up a form, be it for the educational matter or for their professional matter or any other reason, they just could not do that because of lacking of any column as to in which category they are covered. Tensions arose for the same. It was

\footnotetext{
${ }^{10}$ Unnikrishnan v. State of A.P., AIR 1993 SCR 217.
} 
never so easy for the courts to make any such pronouncements. This hassle finally ended up in the landmark judgment ${ }^{11}$ of Supreme Court which is discussed as under:

\section{Path Breaking Judgment of Supreme Court:-}

The National Legal Services Authority of India (NALSA) was the primary petitioner. It had been constituted with the primary objective of providing free legal aid services to the disadvantaged sections of Indian society. The other petitioners in the matter were the Poojya Mata NasibKaurJi Women Welfare Society, a registered society and NGO, and Laxmi Narayan Tripathy, a renowned Hijra activist. ${ }^{12}$ Filed in September, 2012 by National Legal Services Authority, the writ petition had sought several directions from the Supreme Court, including granting of equal rights and protection to transgender persons; inclusion of a third category in recording one's sex/gender in identity documents like the election card, passport, driving license and ration card; and for admission in educational institutions, hospitals, amongst others. The Lawyers Collective had filed an intervention, on behalf of Ms. Laxmi Narayan Tripathy, a Hijra/transgender activist, seeking recognition of self-identified gender of persons, either as male/female/third gender, based on their choice. ${ }^{13}$ It was in the light of that when on 15 April 2014, Justices K.S. Radhakrishnan and A.K. Sikri in the case of NALSA ${ }^{14}$ wherein, the court granted legal recognition to "transgenders" only. The court was of the view that only transgenders or eunuchs will be included in the category of "third gender". "The grammatical meaning of 'transgender', therefore, is across or beyond gender. This has come to be known as umbrella term which includes gay men, lesbians, bisexuals, and cross-dressers within its scope. However, while dealing with the present issue we are not concerned with this aforesaid wider meaning of the expression transgender," the judgment observed. ${ }^{15}$

However Supreme Court also gave direction to Centre and State so as to treat them as socially and educationally backward classes for the purpose of admissions to educational institutions. The Centre which was seeking modification in the SC judgment of 2014, said that it could not implement the judgment as in one of the paragraphs, lesbian, gay and bisexual persons were put along with transgender persons in the third gender category. ${ }^{16} \mathrm{~A}$ bench headed by Justice AK Sikri said that there is no confusion and it had clearly stated that lesbian, gay and bisexual persons do not fall under category of third gender. Appearing for transgenders, senior advocate Anand Grover contended that under the garb of clarification, the government delayed the compliance of the verdict for the past two years. ${ }^{17}$ To this, the court asked Additional Solicitor General Maninder Singh, "Why can't a cost be imposed on the government for the delay in implementation of our order." However, the court disposed of the government's plea without imposing any cost. ${ }^{18}$

The implications of NALSA are far-reaching. With legal status accorded to third gender, transgender persons will be able to enjoy 'full moral citizenship'. ${ }^{19}$ A person's sense of gender will now match their official identity, without

\footnotetext{
${ }^{11}$ National Legal Services Authority v. Union of India, W.P. (C) No. 604 of 2013.

${ }^{12}$ Wikipedia, National Legal Services Authority of India v. Union of India, (Sept. 01, 2016, 01:52 PM) https://en.wikipedia.org/wiki/National_Legal_Services_Authority_v._Union_of_India.

${ }^{13}$ DhananjayMahapatra, Supreme Court recognises the Right to determine and express ones gender grants legal status to third gender, (Sept. 01, 2016, 02:05 PM) http://www.lawyerscollective.org/updates/supreme-court-recognises-the-right-to-determine-andexpress-ones-gender-grants-legal-status-to-third-gender.html.

${ }^{14}$ National Legal Se.Orvices Authority v. Union of India, W.P. (C) No. 604 of 2013.

${ }^{15}$ G. Ramakrishna, Gays, Lesbians, bisexuals are not third gender, (Jun. 29, 2017, 11:30 AM) http://www.thehindu.com/news/national/gays-lesbians-bisexuals-are-not-third-gender-scclarifies/article8792057.ece.

${ }^{16}$ Prabhati Mishra, Supreme Court clarifies 2014 order on transgenders, says lesbian, gay and bisexual people are not third gender, (Jun. 29, 2017, 11:45 AM) http://www.dnaindia.com/india/report-scclarifies-2014-order-on-transgenders-says-lesbian-gay-and-bisexual-people-are-not-third-gender2229641.

${ }^{17}$ Ibid.

${ }^{18}$ Ibid.

${ }^{19}$ DhananjayMahapatra, Supreme Court recognises the Right to determine and express ones gender grants legal status to third gender, (Sept. 01, 2016, 02:05 PM) http://www.lawyerscollective.org/updates/supreme-court-recognises-the-right-to-determine-andexpress-ones-gender-grants-legal-status-to-third-gender.html.
} 
any certificate from a doctor or proof of having undergone sex re-assignment surgery ('SRS'), as the Court clarified that "any insistence for SRS for declaring one's gender is immoral and illegal". ${ }^{20}$ The decision will go a long way in stopping egregious police practices of stripping, feeling up breasts and genitals and subjecting transgender persons to intrusive body searches or medical examination to ascertain their gender. Discrimination in the areas of public employment, health care, education and access to services will be open to challenge and redress. Transgender women may be able to seek protection under gender-specific laws for women. Affirmation of gender identity by the highest Court may also lead families to embrace gender non-conforming members, as was seen after the $\mathrm{Naz}$ Foundation decision in 2009 for homosexual persons. ${ }^{21}$ Notwithstanding the confusion in terms/expressions around gender and sexuality apparent in some parts of the judgment, NALSA is, on the whole, a historic decision that has both strengthened and advanced fundamental rights. It strikes a fine balance between philosophical, legal and practical considerations that surround the area of gender identity and recognition. ${ }^{22}$

\section{Duty of State towards Transgenders:-}

Our State performs various functions with the aim to benefit the society as a whole. The Directive Principles of State Policy are the directions given to the State that incase of framing any policies for the nation, it has to bear in mind the Principles as enshrined under Part IV of the Constitution. The fundamental rights and the directive principles find common origin in the Sapru Report of 1945, which had divided the fundamental rights into two parts viz. Justifiable and non-justifiable rights. While justifiable rights were incorporated in the Part III; non-justifiable rights were incorporated as directive principles to the state without any guarantee to be enforced. ${ }^{23}$

Article 38 of the Constitution under the heading of Directive Principles of State Policy, talks about social, economic and political justice. This Article reads as: "the State to secure a social order with economic, political and social justice for the promotion and welfare of the people." This justice implies justice in all forms to all forms of people including transgenders. After all they are the citizens of India then how can one think of ignoring justice to them. This is another way through which State is under the responsibility to make fruitful provisions for such people as well. Relating the Directive Principles with Fundamental Rights with respect to education, Article 45 states that the State shall endeavor to provide early childhood care and education for all children until they complete the age of six years. What this indicates is that, in case State is to make any such law with to education, the State is to keep in mind the benefits for transgenders as well. As discussed above, we know that the Supreme Court has stated that we need to include such people in the category of socially backward class of persons thereby meaning that such people are considered as under the weaker sections of society. Yes, if that is so then we can interpret it in the light of Article 46 which states that the State shall promote with special care the educational and economic interests of the weaker sections, and, in particular, of the Scheduled Castes and the Scheduled Tribes, and shall protect them from social injustice and all forms of exploitation. This however clearly indicates that if such transgenders are thereby considered as weaker sections of the society then definitely, State is to make efforts for their protection. It very true that such people are usually exploited by the others and in order to prevent their exploitation, State is to act as a guardian.

\section{Conclusion:-}

Our constitution provides equal rights to all people, irrespective of their religion, caste, creed or sex. It forms the basis of our pluralistic society that can progress only when each of its individual is treated equally. Transgenders also form a significant part of our diverse nation. Historically, some of them have been confined to the practices of social function performer and they have been excluded from the developmental policies of the administration from historic times. ${ }^{24}$ Some possible measures that can be implemented are ${ }^{25}$ :

1. People should be encouraged to be more humane in their approach towards transgendered individuals. They need to accept the emotional and physical psychology of members from this community. Regular seminars

\footnotetext{
${ }^{20} \mathrm{Ibid}$.

${ }^{21}$ Ibid.

${ }^{22}$ Ibid.

${ }^{23}$ General Knowledge Today, Directive Principles of State Policy, (Jun. 25, 2017, 10:15 PM) http://www.gktoday.in/directive-principles-of-state-policy/.

${ }^{24}$ Insights Daily Debates, LGBT's Right is every Indian's Right, (Aug. 18, 2016, 03:16 PM) http://www.insightsonindia.com/2016/02/02/insights-daily-debates-day-135-lgbt-right-is-everyindians-right/.

${ }^{25}$ Ibid.
} 
can be organized at the local-level, which promote the general inclusion of transgendered persons in the mainstream society.

2. The print and digital media can also play an important role in representing transgendered communities in an appropriate manner. Often, their problems and demands are not given enough importance, which lead to their continuous physical and mental abuses by different members of the society.

3. Initiatives to impart standardized industrial skills should be implemented at different levels by the government. This will help transgendered individuals to live a life of dignity in the society, and be independent financially.

If today, transgendered community is discriminated though institutional mechanism under the Section 377 of Indian Penal Code, 1860; then similar situations may arise where communities will be differentiated on the basis of their religion or caste, in the name of implementation of law. Such regressive laws should be repealed in order to protect the cultural ethos of our nation. 